\title{
Fatty acid signatures as indicators of diet in great skuas Stercorarius skua, Shetland
}

\author{
Anne Käkelä ${ }^{1}$, Jonathan Crane ${ }^{2}$, Stephen C. Votier ${ }^{2}$, Robert W. Furness ${ }^{2}$, \\ Reijo Käkelä ${ }^{1, *}$ \\ ${ }^{1}$ Department of Biology, University of Joensuu, PO Box 111, 80101 Joensuu, Finland \\ ${ }^{2}$ Institute of Biomedical and Life Sciences, Graham Kerr Building, University of Glasgow, Glasgow G12 8QQ, UK
}

\begin{abstract}
Fatty acid signatures (FAS) were determined in plasma and adipose tissue of great skuas Stercorarius skua from Shetland in order to test the applicability of this biomarker in estimating diets of wild scavenging seabirds. The plasma FAS were compared with those of captive herring gulls Larus argentatus, which were fed typical Northeast Atlantic demersal and pelagic fish. The individual fatty acids that showed the largest proportional changes in FAS due to changes of dietary fish in herring gulls also varied the most in wild great skuas, suggesting a dietary origin of these changes in FAS. Thus, great skuas that had recently been feeding largely on a demersal or terrestrial diet were distinguished from individuals feeding mainly on a pelagic diet. Pronounced variation in the plasma FAS of great skuas suggests either very flexible feeding behaviour or individual dietary specialisation, which concurs with previous studies based on pellets. Individuals that regurgitated pellets consisting only of demersal fish, bird or rabbit showed larger values of a specific polyunsaturated fatty acid ratio $(20: 4 n-6 / 18: 3 n-3+18: 4 n-3+20: 5 n-3)$ than birds whose pellets also contained remains of pelagic fish. Although pellet data showed a clear dominance of demersal fish in the summer diet of the great skua, the large proportions of long-chain monounsaturated fatty acids (e.g. $20: 1 \mathrm{n}-9$ and $22: 1 \mathrm{n}-11$ ) in adipose tissue of the great skua suggest that a considerable part of fat accumulated outside the breeding season comes from fatty pelagic fish.
\end{abstract}

KEY WORDS: Adipose tissue - Fatty acid signatures · Fishery discards · Foraging ecology $\cdot$ Great skua $\cdot$ Plasma $\cdot$ Seabirds $\cdot$ Shetland

\section{INTRODUCTION}

Approximately 20 million tonnes of demersal fish are discarded at sea each year (Alverson et al. 1994). Populations of scavenging seabirds feed extensively on fishery discards, and have increased dramatically in many regions, such as the North Sea (Mitchell et al. 2004), Mediterranean Sea (Oro \& Ruiz 1997), Barents Sea (Anker-Nilssen et al. 2000), Atlantic Canada (Chapdelaine \& Rail 1997) and South America (Bertellotti \& Yorio 2000). Changes in seabird community structure, with relative increases in numbers of large scavenging seabirds, have been particularly strong in areas where fishery discards are plentiful (Furness 2003, Mitchell et al. 2004). Within each seabird community, these large species compete effectively for discarded fish (Garthe et al. 1996, Bertellotti \& Yorio 2000), which is likely to improve their overwinter condition and breeding performance (Hüppop \& Wurm 2000, Davis et al. 2005). However, in the North Sea, declining stocks, changes in technical measures, and the beginning of a recovery programme for cod Gadus morhua have reduced the amount of discards in recent years (Votier et al. 2004a). In addition to the long-term changes in the availability of the discards, the amounts discarded vary from year to year as a result of large fluctuations in fish recruitment and consequent changes in stock age-structure (Stratoudakis et al. 1999). Short-term changes in food supply to longlived seabirds due to sudden reduction in discard rates may result in breeding failures (Oro et al. 1996) or a switch to feeding on smaller seabirds that may have 
severe impacts on other species (Oro \& Furness 2002, Votier et al. 2004b).

The largest colony of great skuas Stercorarius skua in the world at Foula, Shetland (northern North Sea; $60^{\circ} 08^{\prime} \mathrm{N}, 2^{\circ} 05^{\prime} \mathrm{W}$ ), and the smaller nearby colonies, have been under intensive ecological study for decades. At the population level, the great skua can be characterized as a generalist predator, facultative scavenger and a fisher on small pelagic fish (Furness \& Hislop 1981, Phillips et al. 1997, Votier et al. 2003). In addition, its ability to switch prey has been found to lead to increased killing of small seabird species when the rates of discarding and availability of shoaling pelagic fish decrease (Votier et al. 2004a,b). To study these interactions, accurate identification of the birds' diet is needed. The composition of great skua diet has been assessed using several sampling techniques. Conventional methods include regurgitated indigestible material in pellets, prey remains, spontaneous regurgitates, observed feeds and water off-loading by gastric lavage (Votier et al. 2003). Although these methods provide broadly similar estimates of diet composition, the resulting proportions of different dietary items are influenced by the method used. It is known that the most frequently used methods, the collection of pellets and prey remains, overestimate the proportion and metabolic importance of the items that contain mainly indigestible material (Votier et al. 2001, 2003). In addition, in terms of metabolic energy obtained, fatty pelagic fish will be more important than the same mass of lean demersal fish. Stable isotopes of carbon and nitrogen have been used to provide indications of great skua diet, but typically reveal only broad patterns of trophic level and oceanographic water mass from which foods are taken (Bearhop et al. 2001). Therefore, we report here on complementary biochemical markers, fatty acid signatures (FAS), in the predator tissues that have been developed to study the relative importance of different dietary items in the digested food. The stable isotopes and FAS can be complementary, especially as they provide insights about the diet of predators over different time scales (Hobson \& Clark 1992, Käkelä et al. 2005).

FAS provide information on the ingested prey but also on all the organisms of the food chain that have metabolically contributed to the final FAS. The computerised statistical treatments of the FAS data, containing usually 30 to 70 easily detected components, make this method very powerful. There are, however, difficulties in interpreting the results from FAS. Although the fatty acids are largely derived from the dietary items, the fatty acid compositions of the prey are not transferred intact (Dahl et al. 2003, Andersen et al. 2004, Iverson et al. 2004). In addition to structural modifications of fatty acids in tissues, the incorporation of fatty acids into tissue lipids and their mobilization from tissues are selective processes (Zhou \& Nilsson 2001, Heath et al. 2003, Raclot 2003). Therefore, the comparison of the FAS of the dietary items and predator tissues requires calibration. To provide a suitable calibration we fed captive herring gulls Larus argentatus with different demersal and pelagic fish and recorded the consequent changes of FAS in the birds' plasma (Käkelä et al. 2005). The present study of FAS in great skuas from Shetland uses this previous study for calibration. Because the plasma FAS already show large changes $5 \mathrm{~d}$ after a switch of diet (Käkelä et al. 2005), adipose tissue and muscle samples representing longer time windows were collected from fresh carcasses of dead great skuas. The turnover rates of fatty acid composition of adipose tissues vary according to metabolic status from a month to years, and are different for different fatty acids (Foglia et al. 1994, Herzberg \& Skinner 1997, Katan et al. 1997). Thus, it is likely that at least slowly turning over components of adipose tissue FAS indicate winter diet of skuas, as these birds lose mass during the breeding season, but return to the colony in spring at heavy weights due to storage of reserves over winter (Furness 1987, Phillips \& Furness 1997, Kalmbach et al. 2004). When polyunsaturated fatty acids (PUFA) are known to be preferentially mobilized from adipose tissues (Raclot 2003), the muscles with high phospholipid (PL) and PUFA contents preserve their PUFA better, still showing diet induced compositional changes (Soriguer et al. 2000, Newman et al. 2002).

After our previous calibration study of captive herring gulls fed demersal or pelagic fish (Käkelä et al. 2005), we aimed here to test the applicability and value of the FAS approach for studying the foraging ecology of a wild scavenging seabird species, the great skua from Shetland. In addition to comparing the skua FAS with the reference FAS of the gulls, the FAS were also compared with the diet reconstructed from pellets collected in the nest territories of the same individuals, and from voluntary regurgitations of food by skuas caught at Shetland colonies. The numerous plasma samples collected allowed us to study whether there were temporal differences in food between the years 2002 and 2003, and whether the individuals from different colonies had differences in their diets.

\section{MATERIALS AND METHODS}

Sampling. Blood samples were taken (under Home Office licence) from the metatarsal vein of breeding adult great skuas Stercorarius skua. In spring 2002, 76 great skuas from the island of Foula were sampled for fatty acid analysis. In spring 2003, great skua sam- 


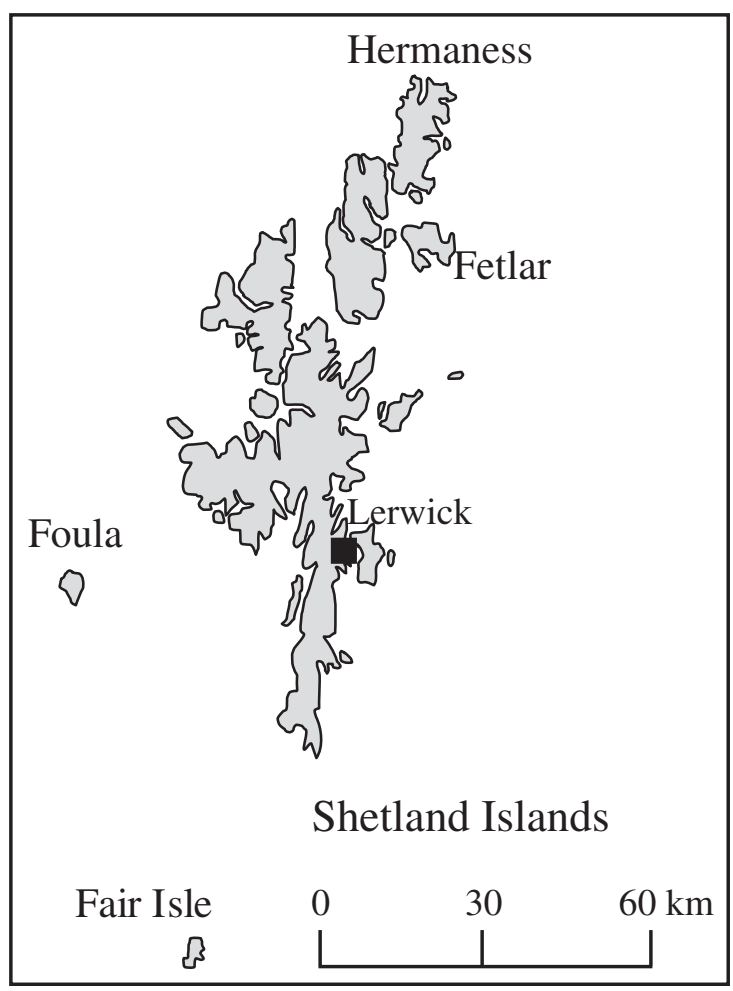

Fig. 1. Stercorarius skua. Locations of the great skua colonies of this study in Shetland

ples were collected from several locations: Foula ( $\mathrm{n}=$ 47), Fair Isle $(n=17)$, Hermaness $(n=14)$ and Fetlar ( $\mathrm{n}=15$ ) (Fig. 1). To prevent blood clotting, EDTA was added to the blood samples, which were then centrifuged to separate plasma. In addition, subcutaneous adipose tissue and muscle samples were collected from fresh carcasses of great skuas found dead on Foula in spring 2003 and 2004 (in these tissues no elevation of free fatty acids or other signs of lipid oxidation were found). The plasma and tissue samples were stored at $-80^{\circ} \mathrm{C}$. The birds found dead had mostly died as a result of territorial fighting with conspecifics, but some may have starved for a few days before dying of their injuries. The great skuas of Foula sampled for blood were measured and weighed. Pellets were collected within the nest territory of each individual and the laying date of the first egg was recorded. We can be confident that pellets had been produced by territory owners, as these birds are highly aggressive in excluding conspecifics from their breeding territory. A small proportion of chicks and a high proportion of adults regurgitate food when trapped and handled. We recorded the type of food regurgitated by adults and chicks caught at all of these colonies in Shetland between 1986 and 2003.

Lipid analysis. The lipid class composition of plasma from the great skua of Foula sampled in 2002 and the studied muscle and adipose tissue samples were analysed using a thin-layer chromatography-FID analyser (TLC-FID, Iatroscan new Mark V). The total lipids were extracted with chloroform-methanol (2:1, vol/vol) according to Folch et al. (1957) and separated on chromarods using petrol ether-diethyl ether-formic acid (67/2.2/0.75 by vol) as eluent. Two replicates were analysed and the detector responses were calibrated with authentic quantitative lipid standards (Sigma).

Fatty acid analysis. The plasma samples were thawed and an aliquot of $200 \mu \mathrm{l}$ was dried under nitrogen and immediately transmethylated by heating with $1 \% \mathrm{H}_{2} \mathrm{SO}_{4}$ in methanol under nitrogen atmosphere. For this methylation step, $50 \mathrm{mg}$ of muscle or adipose tissue was used. The formed fatty acid methyl esters (FAME) were extracted with hexane in 2 steps. The dried and concentrated FAME of the total lipids were analysed by a gas-liquid chromatograph using both flame ionization (FID) and mass detection (6890N network GC with FID and 5973 MSD, Agilent) and DB-wax capillary columns (30 $\mathrm{m}$, inner diameter $0.25 \mathrm{~mm}$, film $0.25 \mu \mathrm{m}, \mathrm{J} \& \mathrm{~W}$ Scientific). Helium was

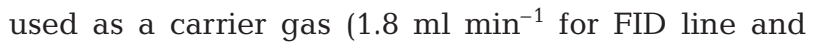

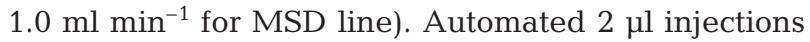
and a split ratio of 1:20 were used. The injectors were set at $250^{\circ} \mathrm{C}$, and the FID and mass interphase were at 250 and $200^{\circ} \mathrm{C}$, respectively. The initial oven temperature of $180^{\circ} \mathrm{C}$ was maintained for $8 \mathrm{~min}$, programmed to rise $3^{\circ} \mathrm{C} \mathrm{min}{ }^{-1}$ to final temperature of $210^{\circ} \mathrm{C}$, which was kept for $25 \mathrm{~min}$. The FAME peaks (from FID) were integrated and the mass spectra of each fatty acid component were extracted using Agilent Chemstation software. The identification of the FAME was based on retention time, mass spectrum and comparisons with authentic (Sigma) and natural standards of known composition and published reference spectra (W.W. Christie, available at www.lipidlibrary.co.uk/ masspec.html). The FID responses were used for quantification and corrected according to the theoretical response factors (Ackman 1992) and calibrations with quantitative authentic standards. The proportions of individual fatty acids were calculated as mol\%.

Multivariate analysis of the fatty acid data. The relationships between the fatty acid compositions of total lipids in different plasma samples were studied by multivariate principal component analysis (PCA) using SIRIUS 6.5 software package (Pattern Recognition Systems) (Kvalheim \& Karstang 1987). The data were standardized (in order not to mask the systematic variance in variables with small variances, each variable was multiplied with the inverse of its SD. After this, every variable has variance equal to 1), and the relative positions of the samples or variables plotted using 2 new coordinates, the principal components PC 1 and PC 2, which represent the largest and second largest vari- 
ance among the samples or variables. In addition, the current fatty acid data of great skua plasma were analysed together with data of plasma fatty acids of captive herring gulls fed different Atlantic pelagic (sardine Sardina pilchardus, mackerel Scomber scombrus and herring Clupea harengus) and demersal (flatfish sp.; mainly plaice Pleuronectes platessa, haddock Melanogrammus aeglefinus and whiting Merlangius merlangus) fish (Käkelä et al. 2005). The FAS of adipose tissues of the birds were compared with those in the pelagic and demersal fish.

Pellet analysis and bird measurements. Pellets were identified and classified into broad categories (sandeel Ammodytes marinus, whitefish-haddock, whiting, blue whiting Micromesistus poutassou and Norway pout Trisopterus esmarkii - herring/mackerel, Goosebarnacle Lepas sp., bird, mammal, egg) according to Votier et al. (2001). Any otoliths present in pellets were assigned to species using Härkönen (1986) and a reference collection of otoliths dissected from fish. In addition, a random sample of fish vertebrae was collected from pellets during the breeding season and identified using Watt et al. (1997). Pellets and remains of birds were classified to the lowest possible taxon, on the basis of feathers, as well as any limbs or skulls.

Standard biometrics were taken for all trapped adults. We also measured pectoral muscle profile, and used these biometrics to generate 2 measures of body condition: pectoral muscle index and body mass index (details in Kalmbach et al. 2004).

\section{RESULTS}

\section{Plasma lipids}

PL, cholesteryl esters (CE), cholesterol and triacylglycerols (TAG) were the major lipid classes in the plasma of great skua Stercorarius skua collected at Foula in 2002 (Table 1). Males had significantly higher plasma concentrations of PL and CE than females. The individual variation in the lipid levels was considerable. The correlations between the plasma concentra-

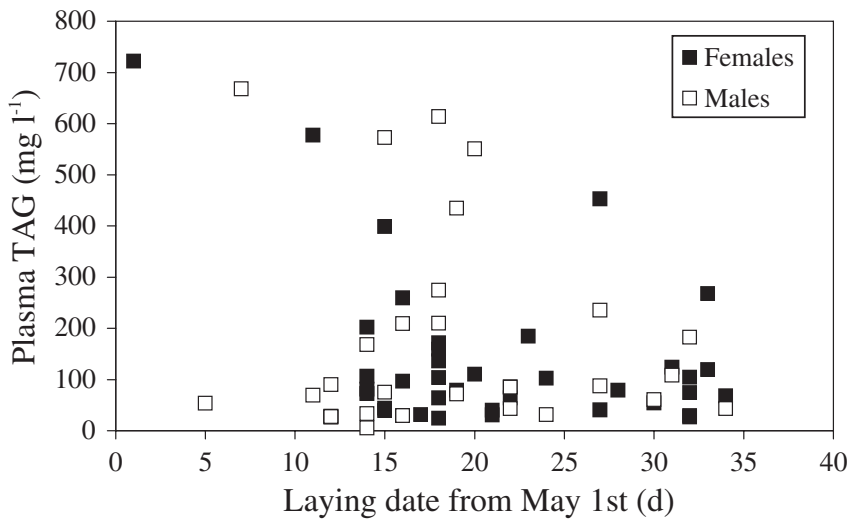

Fig. 2. Stercorarius skua. Plasma triacylglycerol (TAG) concentrations of the great skua (29 males, 39 females) from Foula (2002) according to laying date

tions of PL, CE and TAG were positive with $\mathrm{r}^{2}$-values of 21 to $37 \%$ in both sexes. The concentrations of plasma lipids did not correlate significantly with the mass $(135 \pm 5 \mathrm{~g}$, mean \pm SD; max. $160 \mathrm{~g}$, min. $123 \mathrm{~g})$, or body measures, of these birds. Neither did the proportion of pellets of demersal or pelagic origin collected in the territory of the birds correlate with the plasma lipid concentrations. However, the birds with early laying dates (regardless of sex) had higher maximum levels of plasma TAG than those laying late (Fig. 2). In the birds laying during the first 2 wk of May, the maxima were about $700 \mathrm{mg} \mathrm{l}^{-1} \mathrm{TAG}$, but were $<270 \mathrm{mg}$ in those laying at the start of June in both sexes.

\section{Plasma FAS}

The fatty acid compositions of the great skua plasma contained 28 fatty acids that were present with at least $0.2 \mathrm{~mol} \%$ in the samples collected from either Foula, Fair Isle, Hermaness or Fetlar (Table 2). The FAS of the individual great skuas varied considerably. The relative variations of individual fatty acids in the FAS of the great skua plasma were studied by dividing standard deviations of mol\% with their means (Fig. 3). The relative variations for individual fatty acids were very dif-

Table 1. Stercorarius skua. Concentrations of major lipid classes in plasma of male (n = 29) and female (n = 43) great skuas from Foula sampled in 2002. NS = not significant

\begin{tabular}{|lccccc|}
\hline & \multicolumn{2}{c}{ Males } & \multicolumn{2}{c|}{ Females } & \\
& Mean $\pm \mathrm{SD}$ & Range & Mean \pm SD & Range & \\
\hline Phospholipids $\left(\mathrm{g} \mathrm{l}^{-1}\right)$ & $6.3 \pm 1.8$ & $(2.2-10.7)$ & $5.4 \pm 1.4$ & $(2.9-9.8)$ & $<0.05, t$-test \\
Cholesteryl esters $\left(\mathrm{g} \mathrm{l}^{-1}\right)$ & $4.4 \pm 2.2$ & $(1.1-11.0)$ & $3.1 \pm 1.0$ & $(1.5-5.7)$ & $<0.01$, Mann-Whitney \\
${\text { Cholesterol }\left(\mathrm{g} \mathrm{l}^{-1} \text { ) }\right.}_{\text {Triacylglycerols }\left(\mathrm{g} \mathrm{l}^{-1}\right)}^{0.8 \pm 0.6}$ & $(0.2-2.8)$ & $0.6 \pm 0.2$ & $(0.2-1.1)$ & NS \\
Fatty acids $\left(\mathrm{mg} \mathrm{l}^{-1}\right)$ & $0.18 \pm 0.20$ & $(0.006-0.67)$ & $0.14 \pm 0.15$ & $(0.02-0.72)$ & NS \\
& $81 \pm 59$ & $(14-229)$ & $63 \pm 57$ & $(4-270)$ & NS \\
\hline
\end{tabular}




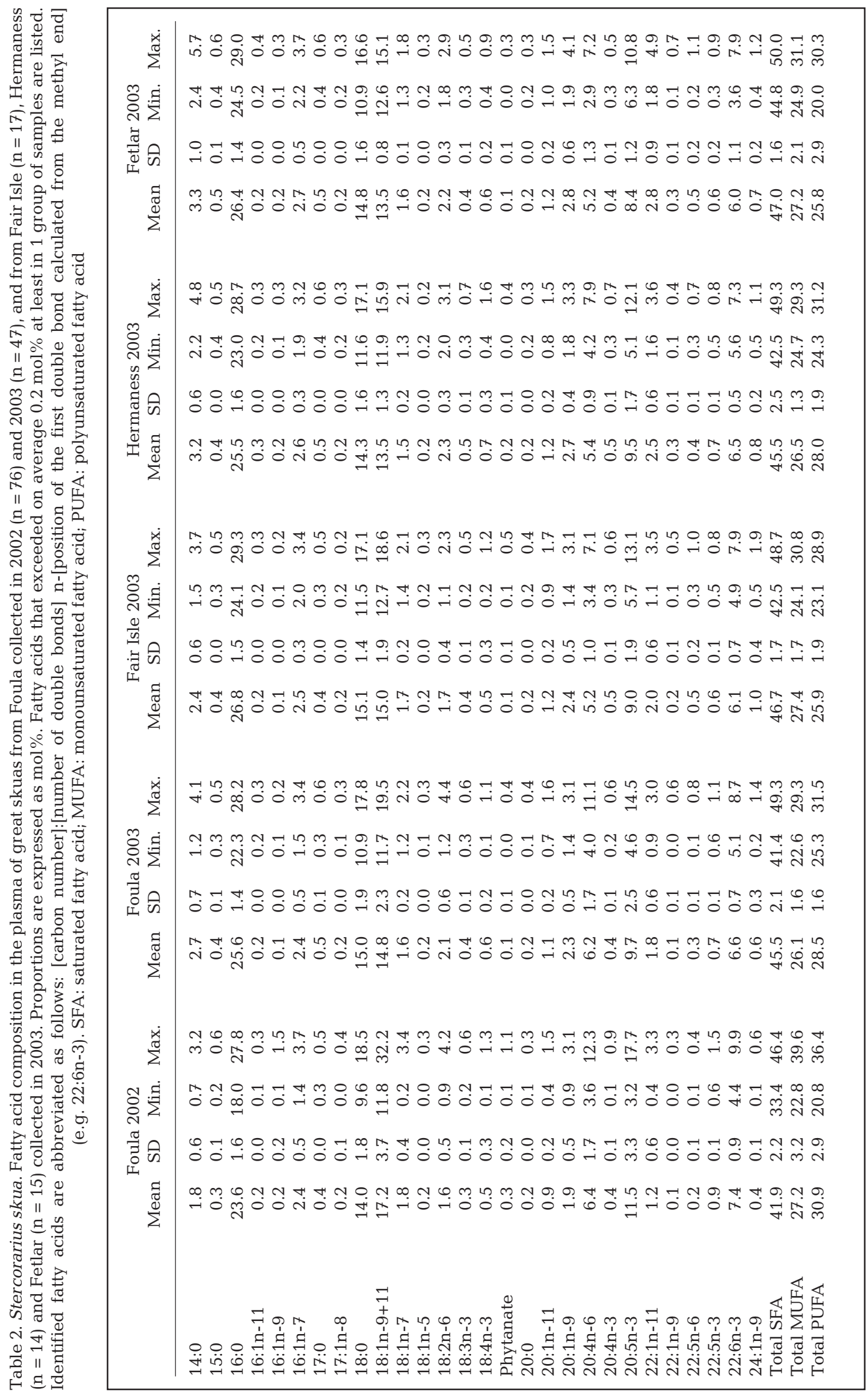




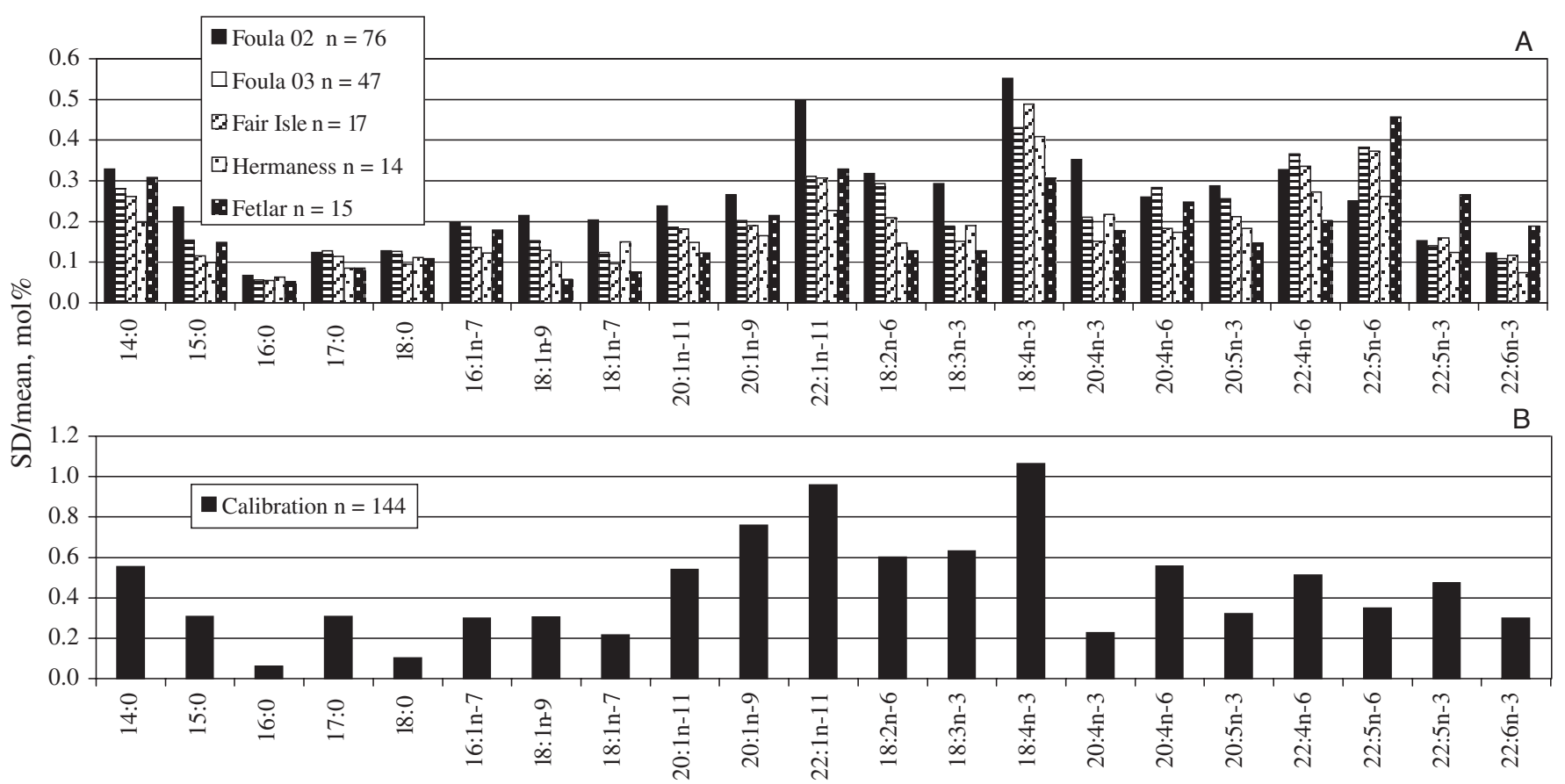

Fig. 3. Stercorarius skua and Larus argentatus. Relative variation (SD/mean) in the proportions (mol\%) of (A) individual fatty acids in the fatty acid signatures of great skua plasma samples collected in Foula (2002 and 2003), Fair Isle (2003), Hermaness (2003) and Fetlar (2003) and (B) the respective values in plasma samples of captive herring gulls fed demersal and pelagic fish (details in Käkelä et al. 2005)

ferent, and clearly orders of magnitude higher than those arising for analytical reasons. It was revealed that among saturated fatty acids 14:0 showed the highest variation. In monounsaturated fatty acids (MUFA) the largest variations were in the long chain MUFA 20:1n11, 20:1n-9 and especially 22:1n-11. In PUFA the variation was the largest in 18:4n-3, but all PUFA had, in general, large variations. The data from wild great skuas were compared with data calculated using our earlier results for captive herring gulls fed controlled demersal and pelagic fish diets (Käkelä et al. 2005). The highest variations in great skua fatty acids were those same fatty acids that varied in the calibration study due to the different diet (Fig. 3).

The relationships of the main fatty acids in the present data were compared with those in the herring gull calibration data. In this respect, there was only one significant difference in these 2 data sets. In the herring gull data where the controlled diet contained only demersal and pelagic fish, 18:2n-6 which was rich in the pelagic fish, correlated positively with the other PUFA characteristic to the pelagic fish (18:3n-3, 18:4n3 and 20:5n-3), and negatively with 20:4n-6 rich in demersal fish. In contrast, in the great skua data 18:2n6 correlated negatively with the mentioned pelagic PUFA and positively with 20:4n-6. Thus, in the great skua 18:2n-6 was not of pelagic origin as in the calibration test. Therefore, in PCA of the combined data of great skua and the herring gulls this fatty acid was not included. The variation in the lipid composition of the plasma samples did not affect in any significant amount the ratios of the most important PUFA or other major components of the FAS.

\section{PCA of plasma FAS}

When the FAS of the great skua plasma samples were subject to PCA using 32 quantitatively most important fatty acids, the formed axes PC1 and PC2 explained 31 and $20 \%$ (next PC3 8\%, not shown) of the variation, respectively (Fig. 4). The fatty acids that, according to the previous calibration study of herring gulls, were enriched in the plasma of the gulls fed demersal fish (e.g. 18:1n-9, 20:4n-6, 18:0 and 18:1n-7) were found on the upper left corner of the plot and those characteristic to pelagic fish diet (e.g. long chain MUFA of zooplankton origin and 14:0) were found on the right. The fatty acids with very low values on axis PC2 were those characteristic of pelagic phytoplankton. The phytoplankton feeding small sandeels were rich in these PUFA but contained little long chain MUFA, compared to the other pelagic fish studied (Table 3).

In PCA a slight difference between the samples from different colonies was found. The samples collected in 


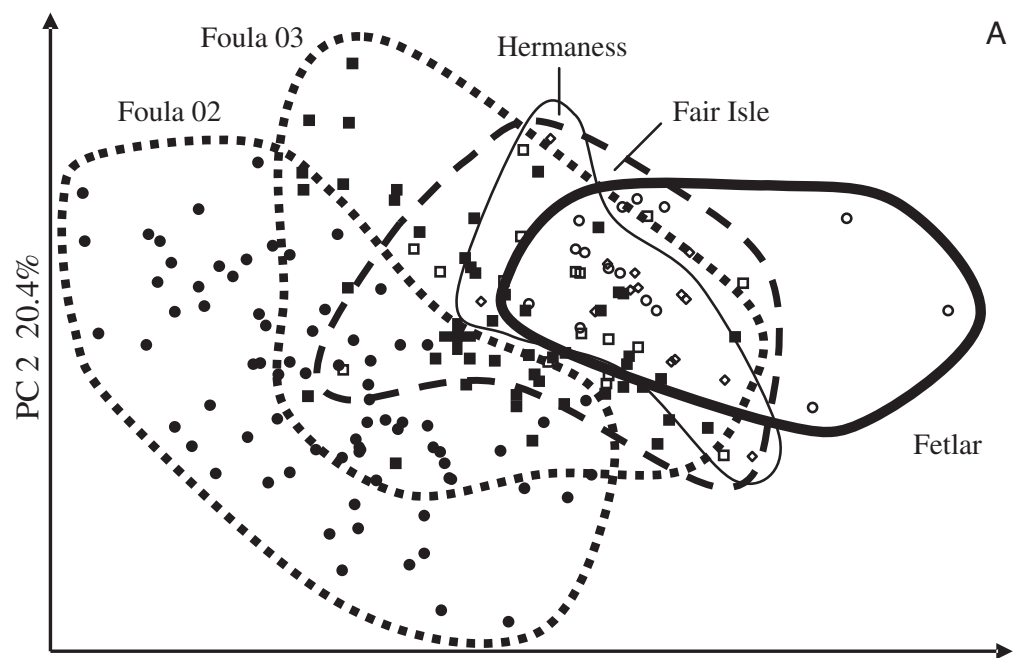

PC $131.2 \%$

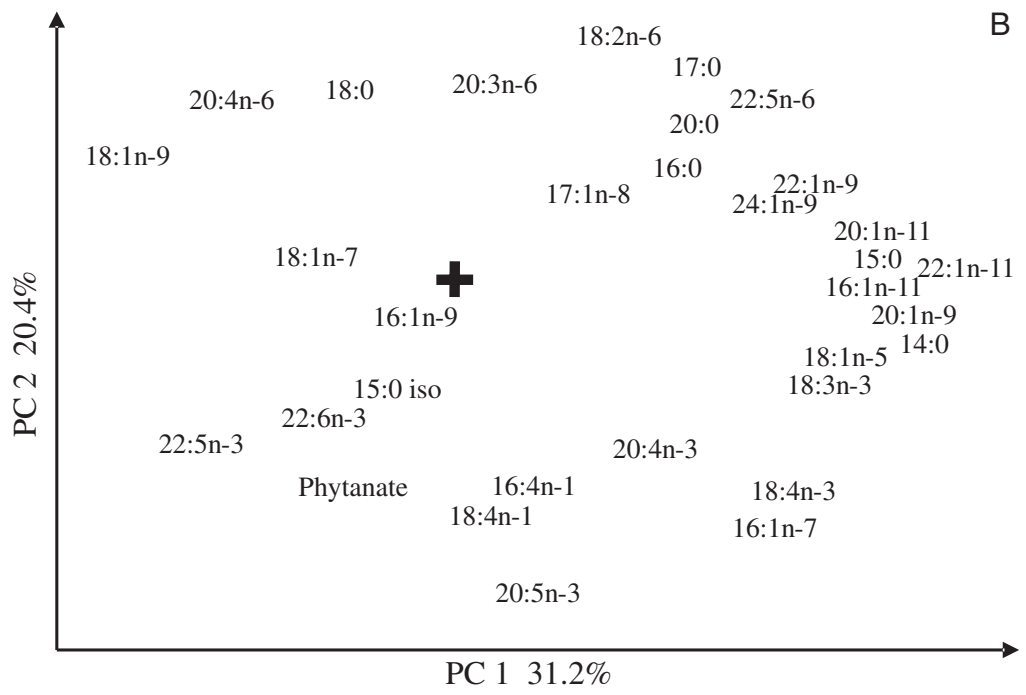

Fig. 4. Stercorarius skua. (A) Principal component analysis of great skua plasma samples collected in Foula (2002 and 2003, $\mathrm{n}=76$ and 47, respectively: and $\square$, respectively), Fair Isle (2003, $\mathrm{n}=17 \mathrm{\text {: }} \square)$, Hermaness (2003, $\mathrm{n}$ $=14: \diamond)$ and Fetlar $(2003, \mathrm{n}=15$ : O). (B) The 32 quantitatively most important fatty acids were used as loadings. The terrestrial/demersal fatty acids were grouped into the upper left corner, phytoplankton fatty acids show low values on PC2 axis, and the zooplankton fatty acids were to the right (see 'Discussion'). Bold cross = origin

Foula contained more individuals with clear demersal or terrestrial characteristics than those from Hermaness, Fair Isle and Fetlar (Fig. 4). The samples with clearest pelagic FAS were collected on Fetlar. In addition to the differences between colonies, the samples collected in Foula during 2002 had lower values on both PC axes, indicating higher percentages of sandeel (small size) type fatty acids and smaller percentages of herring/mackerel type fatty acids, than the samples collected during 2003.

The fatty acid compositions in the great skua plasma (Table 2) were compared with the compositions in the plasma of the captive herring gulls fed different demersal and pelagic diets (Käkelä et al. 2005). In PCA, the calibration data from the herring gull feeding test (without 18:2n-6; see above) formed a clear demersalpelagic axis, from left to right (Fig. 5). In this plot, the relative positions of the great skua from Foula are on the left compared to, for example, the skuas from Fetlar, which may have been consuming slightly more pelagic diet than most of the skuas from Foula. In general, a majority of the skuas are located on the right of the plot, together with the herring gulls fed only pelagic fish.

\section{Comparison of the results of FAS, pellets, and regurgitates}

Regression analysis of the proportions of pelagic and demersal fish remains in the pellets collected from territories of birds in Foula and indicative fatty acid ratios of plasma did not give statistically significant correlations. However, those individuals that had only demersal pellets at their nest site had significantly higher ratio of $20: 4 n-6$ to $(18: 3 n-3+18: 4 n-$ $3+20: 5 n-3$ ) in plasma FAS (Fig. 6), indicative of strong demersal influence (Käkelä et al. 2005), than those that had been consuming some pelagic fish.

Comparing among colonies, regurgitates suggested that great skuas at the most northerly colonies (Fetlar and Hermaness) fed more on herring and mackerel than skuas from Foula or Fair Isle (Table 4). Sandeels were more frequent in regurgitates from Foula, while discards were a major part of the regurgitates at all colonies. The FAS suggest a higher importance of herring/mackerel at Fetlar, and terrestrial/demersal foods at Foula, which accords well with the regurgitate data.

\section{Tissue FAS}

The FAS of adipose tissue (73 to $84 \%$ neutral lipid, TLC-FID) and muscle (66 to $81 \%$ PL) samples from fresh carcasses found on Foula in 2002 and 2003 were studied (Table 5) and compared with those in demersal and pelagic fish. Both the adipose tissue and muscle 
Table 3. Demersal (haddock Melanogrammus aeglefinus, whiting Merlangius merlangus, flatfish sp., mainly plaice Pleuronectes platessa) and pelagic (herring Clupea harengus, sardine Sardina pilchardus, mackerel Scomber scombrus and sandeel Ammodytes marinus) fish species from the North Sea. Major fatty acids (FA) in homogenates of whole fish (means of 6 individuals, except $\mathrm{n}=11$ to 12 for sandeel size classes). Sandeels were divided into 2 size groups according to the fishing device used: a group caught in a Granton trawl ( $\mathrm{n}=12,16$ to $18 \mathrm{~cm}, 11$ to $20 \mathrm{~g}=$ large) and a group caught in a sandeel dredge (n = 11, 10 to $18 \mathrm{~cm}, 3$ to $13 \mathrm{~g}=$ small) in 2005. Fatty acids that exceeded on average $0.5 \mathrm{~mol} \%$ in at least 1 species are listed. Except for sandeel the data were adapted from Käkelä et al. (2005)

\begin{tabular}{|c|c|c|c|c|c|c|c|c|}
\hline $\mathrm{FA}(\mathrm{mol} \%)$ & Haddock & Whiting & Flatfish & Herring & Sardine & Mackerel & Sandeel (large) & Sandeel (small) \\
\hline $14: 0$ & 3.2 & 1.2 & 2.9 & 5.4 & 8.9 & 7.4 & 7.5 & 4.2 \\
\hline $15: 0$ & 0.8 & 0.6 & 0.9 & 0.5 & 0.8 & 0.7 & 0.5 & 0.5 \\
\hline $16: 0$ & 15.2 & 17.9 & 15.8 & 20.5 & 19.4 & 15.9 & 18.5 & 22.4 \\
\hline $16: 1 n-9$ & 0.5 & 0.4 & 0.9 & 0.3 & 0.2 & 0.2 & 0.2 & 0.3 \\
\hline $16: 1 n-7$ & 4.9 & 3.0 & 6.2 & 3.5 & 10.2 & 5.3 & 6.4 & 4.5 \\
\hline $16: 2 n-4$ & 0.2 & 0.2 & 0.4 & 0.2 & 0.9 & 0.3 & 0.3 & 0.4 \\
\hline $16: 4 n-1$ & 0.1 & 0.1 & 0.4 & 0.2 & 0.9 & 0.4 & 1.7 & 0.5 \\
\hline $17: 0$ iso & 0.5 & 0.7 & 0.9 & 0.2 & 0.1 & 0.3 & 0.2 & 0.3 \\
\hline 17:0 anteiso & 0.3 & 0.6 & 0.8 & 0.1 & 0.1 & 0.1 & 0.1 & 0.1 \\
\hline $17: 0$ & 0.6 & 0.9 & 0.9 & 0.3 & 0.6 & 0.5 & 0.3 & 0.4 \\
\hline $17: 1 \mathrm{n}-8$ & 0.7 & 0.7 & 0.8 & 0.2 & 0.2 & 0.4 & 0.1 & 0.2 \\
\hline $18: 0$ & 4.0 & 6.3 & 5.1 & 2.5 & 3.0 & 3.0 & 3.1 & 4.8 \\
\hline 18:1n-13 & 0.2 & 0.9 & 1.4 & Trace & Trace & Trace & Trace & Trace \\
\hline $18: 1 n-9+11$ & 12.9 & 8.8 & 6.5 & 9.7 & 5.7 & 11.4 & 5.6 & 7.1 \\
\hline $18: 1 \mathrm{n}-7$ & 3.7 & 4.8 & 5.2 & 2.8 & 2.4 & 2.3 & 1.8 & 2.3 \\
\hline $18: 1 n-5$ & 0.5 & 0.6 & 0.3 & 0.5 & 0.2 & 0.4 & 0.3 & 0.5 \\
\hline $18: 2 n-6$ & 1.6 & 0.5 & 0.6 & 1.7 & 1.3 & 1.6 & 1.6 & 1.5 \\
\hline $18: 3 n-3$ & 1.2 & 0.2 & 0.2 & 0.9 & 0.9 & 1.3 & 0.9 & 1.0 \\
\hline $18: 4 n-3$ & 2.4 & 0.3 & 0.5 & 1.4 & 1.7 & 3.8 & 3.3 & 2.0 \\
\hline $20: 1 n-11$ & 1.3 & 0.8 & 1.6 & 0.7 & 0.7 & 0.7 & 0.5 & 0.3 \\
\hline $20: 1 n-9$ & 2.6 & 1.1 & 0.9 & 5.2 & 5.1 & 8.0 & 8.5 & 3.4 \\
\hline $20: 1 n-7$ & 1.0 & 1.0 & 1.7 & 0.2 & 0.2 & 0.3 & 0.2 & 0.2 \\
\hline $20: 2 n-6$ & 0.6 & 0.4 & 0.4 & 0.2 & 0.2 & 0.3 & 0.2 & 0.2 \\
\hline $20: 4 n-6$ & 1.7 & 3.3 & 3.3 & 1.0 & 0.7 & 0.7 & 0.6 & 0.9 \\
\hline $20: 4 n-3$ & 0.7 & 0.5 & 0.5 & 0.6 & 0.7 & 1.1 & 0.5 & 0.5 \\
\hline $20: 5 n-3$ & 12.0 & 13.8 & 19.3 & 8.2 & 9.5 & 5.9 & 9.7 & 11.5 \\
\hline $21: 5 n-3$ & 0.3 & 0.3 & 0.6 & 0.2 & 0.3 & 0.3 & 0.3 & 0.3 \\
\hline $22: 1 n-11$ & 2.0 & 0.1 & 0.1 & 8.2 & 7.1 & 10.3 & 9.7 & 4.2 \\
\hline $22: 1 n-9$ & 0.3 & 0.2 & 0.1 & 0.4 & 0.5 & 0.9 & 0.8 & 0.3 \\
\hline $22: 4 n-6$ & 0.6 & 2.1 & 2.0 & 0.3 & 0.2 & 0.2 & 0.4 & 0.3 \\
\hline $22: 5 n-6$ & 0.4 & 0.5 & 0.5 & 0.3 & 0.3 & 0.3 & 0.1 & 0.2 \\
\hline $22: 5 n-3$ & 1.2 & 3.6 & 5.4 & 0.9 & 1.1 & 1.3 & 0.7 & 0.8 \\
\hline $22: 6 n-3$ & 16.7 & 17.4 & 6.7 & 18.7 & 11.4 & 9.1 & 9.6 & 18.3 \\
\hline $24: 1 n-9$ & 0.4 & 0.7 & 0.1 & 0.6 & 0.5 & 0.8 & 0.9 & 1.1 \\
\hline Total SFA & 27.0 & 30.8 & 29.8 & 31.2 & 34.9 & 30.0 & 30.8 & 33.6 \\
\hline Total MUFA & 32.0 & 24.3 & 27.4 & 33.3 & 33.7 & 42.1 & 36.9 & 26.7 \\
\hline Total PUFA & 41.0 & 44.9 & 42.7 & 35.6 & 31.5 & 27.9 & 31.8 & 39.5 \\
\hline
\end{tabular}

contained high proportions of long chain MUFA, 20:1n-9 and 22:1n-11 ( 7 and $10 \mathrm{~mol} \%$ in muscle, and 10 and $18 \mathrm{~mol} \%$ in adipose tissue, respectively), and thus on the PCA plot the tissue sample FAS were located near those of pelagic fish (Fig. 7).

\section{DISCUSSION}

\section{Plasma lipids}

The discovery that lipid levels were higher in male skuas than in females was not anticipated. Great skuas show sexual size dimorphism, and corresponding divi- sion of labour while breeding. The larger female remains on the territory most of the time, taking the primary responsibility for guarding the eggs or chicks, while the smaller male takes the primary responsibility for foraging, providing food not only for himself and the chicks, but also for the female (Furness 1987). Since concentrations of all major lipid classes of bird plasma reflect their nutritional status (Guglielmo et al. 2002), higher lipid levels in males may indicate more frequent feeding and steadier lipid transport in circulation, apparently due to their role as food provider for the family. There are no data on the metabolic rates of male and female great skuas while breeding, but it is likely that male great skuas have a higher metabolic 


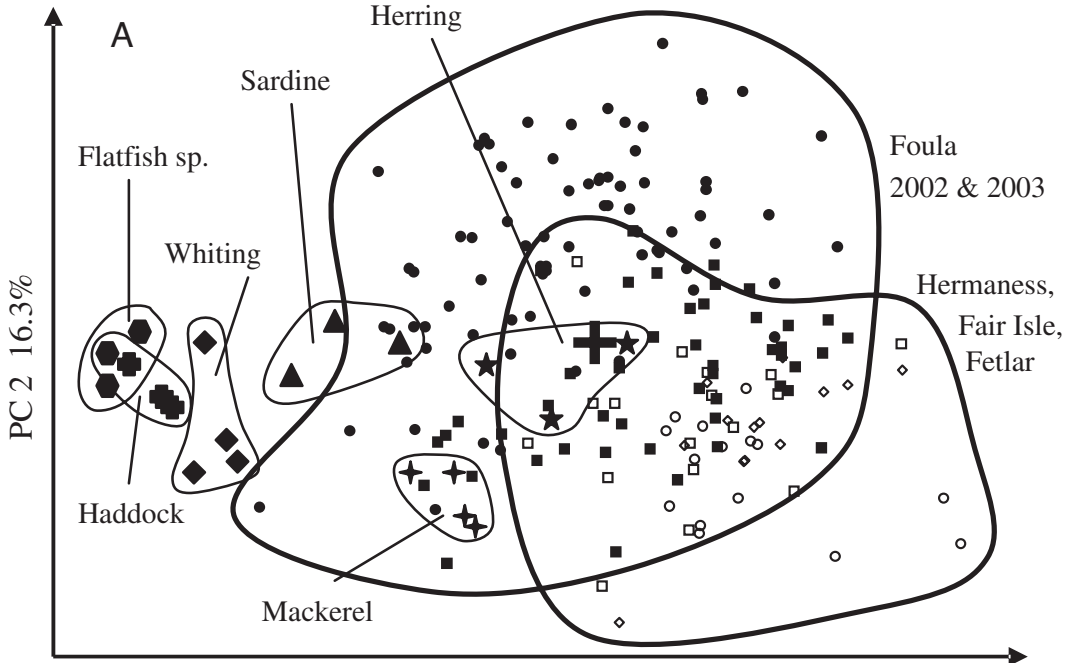

PC $154.8 \%$

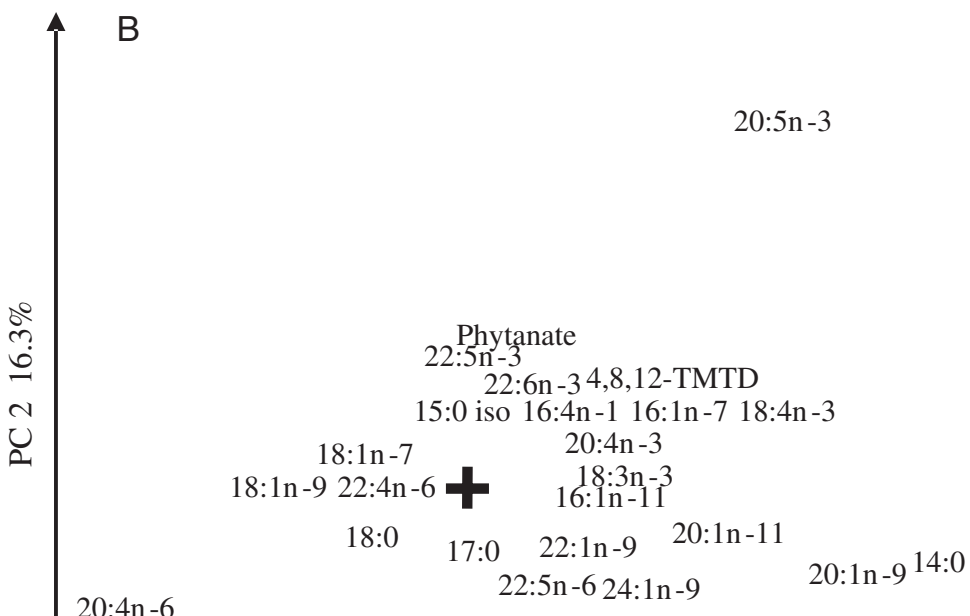

$22: \ln -11$

\section{$\mathrm{PC} 154.8 \%$}

Fig. 5. Stercorarius skua and Larus argentatus. PCA plot of the relationships of the great skua and captive herring gull plasma samples according to fatty acid composition (A). Great skua samples were obtained from Foula (2002 and 2003, - and $\square$, respectively), Fair Isle ( $\square)$, Hermaness $(\diamond)$ and Fetlar (O) (2003). Herring gull plasma samples are indicated by the name of the dietary fish species and large black symbols. (B) A plot of the relationships of the individual fatty acids in the plasma samples of the great skua and herring gulls. Fatty acids with very small loadings (close to origin) are not shown. Bold cross = origin lipids in birds that breed earlier may reflect differences in quality/condition between birds. Earlier breeding is one of the best indices of individual quality or breeding performance, as the breeding success of great skuas, as with most birds, declines progressively with laying date (Votier et al. 2004b).

\section{Plasma FAS}

Since fatty acyl moieties of all major lipid classes of vertebrate plasma reflect dietary input but with different half-times of incorporation into the lipids, the use of total lipid FAS of plasma gives relevant information on dietary fatty acid supply, but the time window of total lipid FAS is longer than when using the neutral lipid FAS of animals in fattening state (Katan et al. 1997). For example, in migrating western sandpipers Calidris mauri, large changes found in fatty acid composition of plasma PL were in many respects similar to contemporaneous fatty acid changes in adipose tissue TAG (Guglielmo et al. 2002). It was concluded that both the plasma concentration and fatty acid composition of neutral lipids and PL reflected the characteristics of dietary lipids. A recent epidemiologic study showed that whole blood is also a suitable biomarker of long-term fatty acid intake, thus offering a potential choice, requiring minimum sample processing, for ecological studies with numerous samples (Baylin et al. 2005).

The total lipid FAS of great skua plasma showed variation in relative amounts of certain fatty acids and rather little variation in amounts of rate and thus larger rate of lipid transport via circulation than females, since the daily energy expenditure of breeding seabirds is strongly influenced by the amount of time spent foraging (Ellis \& Gabrielsen 2002), which is higher in males than in females (Furness 1987, Caldow \& Furness 2000). Higher maximum levels of
Table 4. Stercorarius skua. Regurgitated food from great skuas handled at different Shetland colonies between 1986 and 2003

\begin{tabular}{|lrcccr|}
\hline Colony & $\mathrm{n}$ & $\begin{array}{c}\text { Herring or } \\
\text { mackerel (\%) }\end{array}$ & $\begin{array}{c}\text { Demersal fish } \\
\text { (discards) }(\%)\end{array}$ & $\begin{array}{c}\text { Sandeels } \\
(\%)\end{array}$ & $\begin{array}{c}\text { Birds } \\
(\%)\end{array}$ \\
\hline Fetlar & 6 & 50 & 50 & 0 & 0 \\
Hermaness & 82 & 23 & 74 & 0 & 3 \\
Foula & 590 & 16 & 47 & 30 & 7 \\
Fair Isle & 20 & 5 & 75 & 5 & 15 \\
\hline
\end{tabular}


others (Fig. 3). Those fatty acids showing the greatest variability between skuas were the same ones that showed greatest change in the plasma of captive herring gulls switched between demersal and pelagic fish diets. This result indicates that the individual differences in FAS between skuas are likely to relate to dietary differences between skuas, with the same physiological processes in skuas and gulls. Logically,

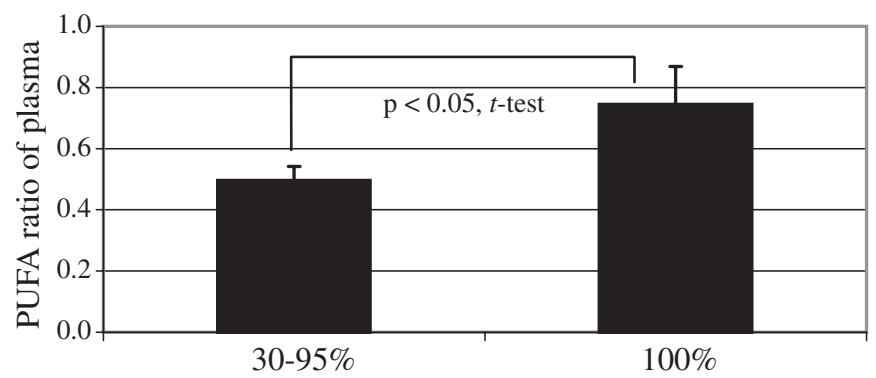

Fig. 6. Stercorarius skua. PUFA ratio 20:4n-6/(18:3n-3+18:4n$3+20: 5 n-3)$ in plasma total fatty acids of great skua from Foula (2002) that according to pellet analysis had fed 30 to $95 \%$ ( $\mathrm{n}=$ 33) or $100 \%(n=26)$ demersal or terrestrial dietary items (means $\pm \mathrm{SE}, \mathrm{p}<0.05, t$-test)

Table 5. Stercorarius skua and Fulmarus glacialis. Fatty acid composition (FA) in subcutaneous adipose tissue $(n=13)$ and muscle $(n=17)$ obtained from fresh carcasses of great skua from Foula, Shetland Islands, in 2003 to 2004. FA means $>0.5 \%$ in one tissue were listed. Reference data of adipose tissue triacylglycerols of northern fulmar $(n=5)$ from Spitsbergen feeding on pelagic prey were added for comparison (adapted from Dahl et al. 2003). $\mathrm{NR}=$ not recorded

\begin{tabular}{|c|c|c|c|c|c|c|}
\hline \multirow{3}{*}{$\begin{array}{l}\text { FA } \\
(\mathrm{mol} \%)\end{array}$} & \multicolumn{4}{|c|}{ Great skua } & \multirow{2}{*}{\multicolumn{2}{|c|}{$\begin{array}{l}\text { Northern fulmar } \\
\text { Adipose tissue }\end{array}$}} \\
\hline & \multicolumn{2}{|c|}{ Muscle } & \multicolumn{2}{|c|}{ Adipose tissue } & & \\
\hline & Mean & $\mathrm{SD}$ & Mean & $\mathrm{SD}$ & Mean & $\mathrm{SD}$ \\
\hline $14: 0$ & 1.6 & 1.6 & 4.0 & 2.7 & 2.4 & 0.5 \\
\hline $16: 0$ & 11.4 & 5.1 & 14.4 & 4.3 & 11.8 & 3.1 \\
\hline $16: 1 n-7$ & 2.4 & 1.5 & 2.8 & 1.4 & 7.1 & 1.3 \\
\hline 18:0 & 10.3 & 4.4 & 4.4 & 1.1 & 3.8 & 1.0 \\
\hline $18: 1 n-9(+n-11)$ & 26.6 & 9.4 & 24.9 & 9.0 & 20.4 & 6.8 \\
\hline $18: 1 n-7$ & 1.8 & 0.5 & 1.9 & 0.4 & 4.7 & 1.2 \\
\hline $18: 2 n-6$ & 4.3 & 1.7 & 1.8 & 0.8 & 1.4 & 0.3 \\
\hline $18: 3 n-3$ & 0.7 & 0.4 & 0.5 & 0.4 & 0.6 & 0.3 \\
\hline $18: 4 n-3$ & 0.3 & 0.4 & 0.8 & 1.0 & 1.0 & 0.5 \\
\hline $20: 1 n-11$ & 4.5 & 1.9 & 2.2 & 1.0 & NR & NR \\
\hline $20: 1 n-9$ & 7.2 & 2.1 & 10.5 & 3.0 & 18.1 & 8.6 \\
\hline $20: 1 n-7$ & 0.2 & 0.1 & 0.4 & 0.2 & 0.5 & 0.4 \\
\hline $20: 4 n-6$ & 6.1 & 4.9 & 0.3 & 0.2 & 0.2 & 0.2 \\
\hline $20: 5 n-3$ & 3.0 & 1.6 & 1.3 & 1.8 & 4.4 & 2.0 \\
\hline $22: 1 n-11$ & 9.6 & 4.6 & 18.2 & 4.1 & 13.8 & 6.5 \\
\hline $22: 1 n-9$ & 1.3 & 0.7 & 1.7 & 0.4 & 0.4 & 0.6 \\
\hline $22: 5 n-3$ & 0.4 & 0.2 & 0.5 & 0.3 & 1.3 & 0.3 \\
\hline $22: 6 n-3$ & 2.2 & 1.3 & 2.5 & 2.4 & 6.2 & 1.6 \\
\hline $24: 1 n-9$ & 0.6 & 0.4 & 0.7 & 0.2 & 0.4 & 0.4 \\
\hline Total SFA & 25.2 & 5.8 & 28.0 & 6.3 & 18.6 & 4.4 \\
\hline Total MUFA & 55.8 & 8.6 & 59.6 & 12.1 & 65.8 & 9.0 \\
\hline Total PUFA & 19.0 & 5.7 & 12.4 & 6.3 & 15.6 & 4.7 \\
\hline
\end{tabular}

the principal products of the endogenous fatty acid synthesis of a vertebrate, 16:0 and 18:0, had the lowest deviations and were followed by their immediate desaturation products $16: 1 \mathrm{n}-7$ and $18: 1 \mathrm{n}-9$. In the case of $18: 2 n-6$ the relationship with other fatty acids was different between skuas and gulls, and we excluded this fatty acid from further consideration. Although $18: 2 n-6$ is plentiful in pelagic fish it is also the most important PUFA of terrestrial prey. In addition, feeding the captive herring gulls before the feeding experiment for a long time with commercial pellets of mainly terrestrial origin may have shifted the plasma FAS of these gulls in a terrestrial/demersal direction which is opposite to that of pelagic fish (Fig. 5). The remaining data showed a pattern in wild skuas that corresponded to that in captive gulls, with clear discrimination in a PCA loadings plot (Fig. 4, lower panel) between fatty acids characteristic of terrestrial/demersal fatty acids (e.g. 20:4n-6, 18:0, 18:1n9) phytoplankton fatty acids (e.g. 20:5n-3, 18:4n-3, 20:4n-3, 16:4n-1, 18:4n-1) and zooplankton fatty acids (e.g. 20:1n-9 and 22:1n-11) (Ackman et al. 1968, Saito \& Kotani 2000, Dalsgaard et al. 2003, Käkelä et al. 2005). These results give us confidence that the FAS of wild great skuas provide a means of identifying the type of food being taken by free-living skuas. The plasma FAS of great skuas showed a wide variation between individual skuas, which is consistent with previous research showing that these birds display both a wide spectrum of diets across a population, and considerable individual specialisation in diet (Furness \& Hislop 1981, Phillips et al. 1997, Votier et al. 2003). Comparing FAS of great skuas from different colonies in Shetland, we found a tendency for birds at Hermaness and Fetlar to have plasma FAS indicative of a higher proportion of pelagic fish in the diet. This trend is also evident in the data on regurgitated foods found at these colonies (Table 4), suggesting that the plasma FAS provides a useful method of identifying both individual dietary specialisations and differences in diet composition between colonies/populations. However, obtaining plasma samples can be easier than obtaining regurgitates, especially from chicks, and so may provide not only a less biased, but also a more convenient means of sampling seabird diet.

Interestingly, the FAS of plasma samples collected at Foula showed a temporal 


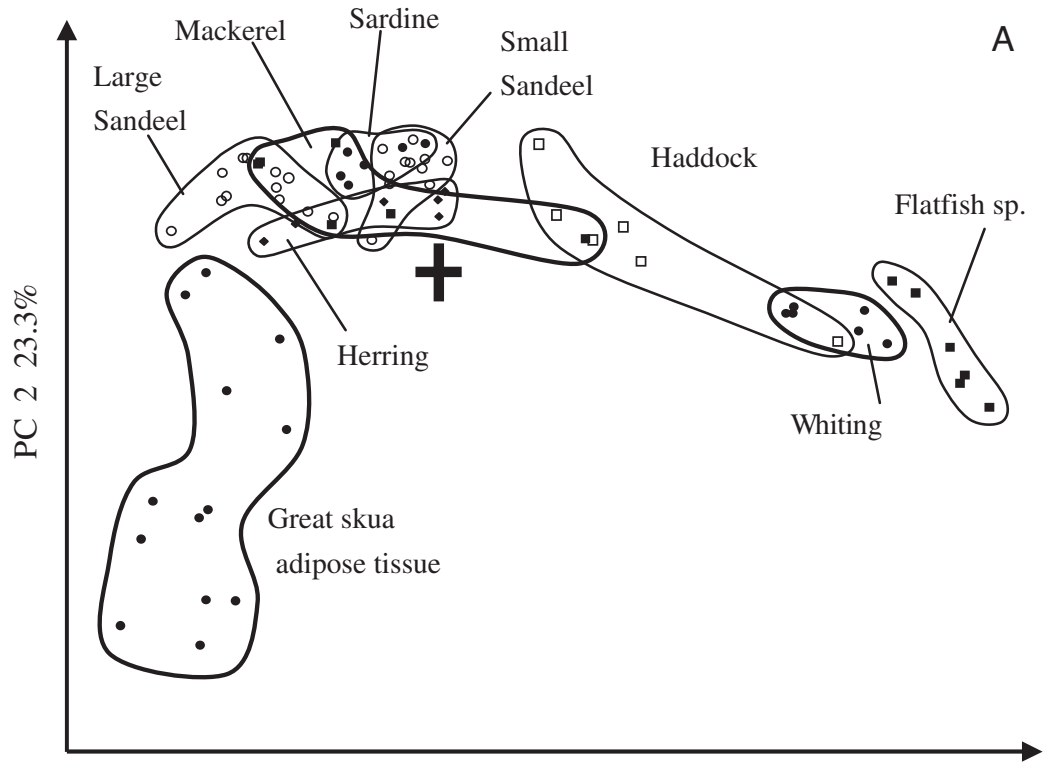

PC $140.2 \%$

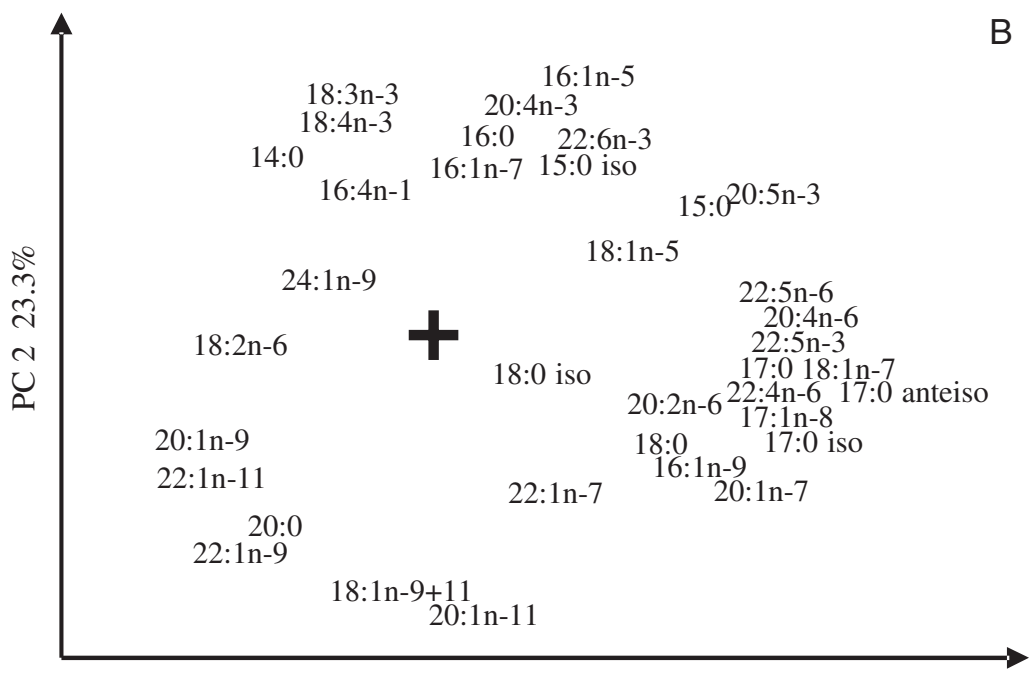

PC $140.2 \%$

Fig. 7. Stercorarius skua. PCA plot of the relationships of the FAS in great skua adipose tissue samples collected on Foula in 2003 and 2004 and in the potential demersal and pelagic prey (see Table 3). (A), (B) = relationships of samples and fatty acids, respectively; bold cross = origin

shift towards larger values of long chain MUFA and smaller values of phytoplankton type PUFA from 2002 to 2003. The long chain MUFA are characteristic for herring and mackerel and originate from pelagic zooplankton, whereas the main fish species representative for the phytoplankton type PUFA without the long chain MUFA in the diet of North Sea seabirds is smallsize sandeel (Table 3). The year 2003 was exceptional in Shetland as the population of sandeels collapsed to the lowest level on record (Fisheries Research Service survey data, P. Kunzlik unpubl. data, Mavor et al. 2004). It is possible that the FAS of great skua plasma indicate this change in the available fish diet and also suggest that the skuas compensated for the decreased availability of large shoals of small sandeels by increasing their consumption of herring/mackerel or larger sandeels. It should be recalled that both among- and within-species variability exists in the FAS of fish and their food webs (Budge et al. 2002, Iverson et al. 2002).

Comparison of FAS and pellets of particular pairs of great skuas at Foula showed a difference in FAS between birds with only demersal fish in the pellets and those taking some pelagic fish, but failed to show a clear correlation between FAS and the proportion of pelagic fish pellets present. Possibly it may be more difficult to discriminate between birds with higher and lower proportions of pelagic fish in the diet, given that pelagic fish usually have a much higher lipid content than demersal fish (Iverson et al. 2002), so that even with a relatively small proportion of pelagic fish being eaten, most of the fatty acids will derive from the pelagic fish rather than from the demersal fish. In this respect, FAS may be more effective at identifying individuals that do not eat pelagic fish rather than identifying individuals that eat different proportions of pelagic fish. Thus in this work we have kept our examination at qualitative or at best at semiquantitative level. To produce reliable quantitative estimates of the diets of the opportunistic great skuas down to the species level, a large reference material that covers FAS variation due to geographic, temporal and biological factors must be collected and analysed (see Iverson et al. 2004). In addition, feeding experiments with mixed diets containing fish with different FAS and lipid contents are needed to test the additivity of FAS after assimilation and in a particular tissue.

FAS, pellet and regurgitate data showed consistent differences in great skua diet between colonies, with birds from northern Shetland (Fetlar and Hermaness) feeding more on herring and mackerel. However, these data also indicate some limitations of the use of regurgitates and pellets. In order to acquire satisfactory sample sizes it was necessary to pool data collected over many years. This is especially true of regur- 
gitate data, as only about 2 to $5 \%$ of chicks regurgitate food when handled. It is known that there have been large changes in the abundance of sandeels and of discarding rates in Shetland over recent years (Votier et al. 2004b), but the small numbers of regurgitates and pellets that can be obtained from short visits to several colonies preclude analysis of such patterns. It is reassuring that despite these limitations, the FAS, pellet and regurgitate data all show similar geographical pattern in diet composition. Of the 3 methods, obtaining plasma from chicks for FAS provides the simplest way to get large sample sizes from several colonies in a single season, so has clear advantages over collection of regurgitates or pellets.

\section{Tissue FAS}

The diets of great skuas in winter are not known. These birds leave the breeding colony in late summer, and migrate to winter quarters at sea over the continental shelf from the Bay of Biscay to the western Mediterranean and north-west Africa (Wernham et al. 2002). It is possible that great skuas feed on fishery discards during winter, or on small pelagic fish or seabirds killed at sea (Furness 1987). It is common to see great skuas in their winter quarters following fishing vessels, and so a diet including discarded demersal fish seems likely. However, accumulation of fatty acids characteristic for pelagic fish in the tissue FAS of the great skua suggests that pelagic fish are an important source of lipids and metabolic energy in the winter diet.

Adipose tissue of great skua showed FAS rather similar to that found previously in northern fulmars Fulmarus glacialis from Svalbard which were thought to be feeding on pelagic prey (Dahl et al. 2003) (although fulmars of the North Sea feed extensively on waste from trawl fisheries). The FAS of great skua adipose tissue with strikingly high percentages of 20:1n-9 and 22:1n-11 appeared to be much closer to the FAS of pelagic fish than to the FAS of demersal fish (Fig. 7). These long chain MUFA known to originate from zooplankton wax esters (Saito \& Kotani 2000, Dalsgaard et al. 2003) were present with high percentages also in the muscle samples of the great skua. Although in the case of king penguins Aptenodytes patagonicus the FAS of subcutaneous adipose tissue was reported to be identical to that of the diet (Raclot et al. 1998), this may not apply to scavenging seabirds of the North Sea. There is the possibility that FAS of adipose tissue alters in starvation or during continuous cycles of fat mobilization and deposition. In mammals, the mobilization of fatty acids is selective, and favours short-chained and highly unsaturated fatty acids (Raclot 2003). Consequently the relative amounts of long chain MUFA increase during starvation. Thus, FAS from adipose tissue may also alter according to the nutritional history of individual birds. Within the North Sea, scavenging seabirds tend to feed more on discards in winter than in summer (Garthe et al. 1996), but this pattern largely reflects the fact that sandeels remain unavailable to surface-feeding seabirds during winter, but are available in summer when they come to feed on plankton in the upper layers of the sea (Furness 2002). In their wintering areas, however, great skuas would probably not feed on sandeels, but rather on sardines, anchovies or possibly horse-mackerel Trachurus trachurus, fatty pelagic species that do not show the strong seasonal availability to surface-feeding seabirds that is characteristic of sandeels. This would be consistent with the strong signal of the long chain MUFA of pelagic origin in the tissue FAS of the great skuas.

Given the possibility to identify the kinds of foods taken by seabirds during winter by analysis of adipose tissue sampled at other times of year (most easily during the breeding season when birds can be caught at the colony), it will be important to test the assumption that adipose tissue is primarily deposited during winter in seabirds. Given the strong seasonal variation in body mass, with most breeding seabirds losing considerable body mass during the breeding season (Phillips \& Furness 1997, Kalmbach et al. 2004), it seems likely that the adipose tissue FAS of the birds returning to the breeding colony show signs of the winter diet (Foglia et al. 1994, Herzberg \& Skinner 1997, Katan et al. 1997). However, it could be tested by sampling FAS in the adipose tissue of species of birds that are known to switch between completely different diets in summer and winter. Nevertheless, this approach has the potential to provide unique information about winter diets of seabirds.

Acknowledgements. This study was supported by EU contract Q5RS-2001-00839 'DISCBIRD'.

\section{LITERATURE CITED}

Ackman RG (1992) Application of gas-liquid chromatography to lipid separation and analysis: qualitative and quantitative analysis. In: Chow CK (ed) Fatty acids in foods and their health implications. Marcel Dekker, New York, p 47-63

Ackman RG, Tocher CS, McLachlan J (1968) Marine phytoplankter fatty acids. J Fish Res Board Can 25:1603-1620

Alverson DL, Freeberg MH, Murawski SA, Pope JG (1994) A global assessment of fisheries bycatch and discards. FAO Fish Tech Pap 339

Andersen SM, Lydersen C, Grahl-Nielsen O, Kovacs KM (2004) Autumn diet of harbour seals (Phoca vitulina) at Prins Karls Forland, Svalbard, assessed via scat and fattyacid analyses. Can J Zool 82:1230-1245 
Anker-Nilssen T, Bakken V, Strøm H, Golovkin AN, Bianki VV, Tatarinkova IP (2000) The status of marine birds breeding in the Barents Sea region. Norsk Polarinstitutt, Tromsø

Baylin A, Kim MK, Donovan-Palmer A, Siles X, Dougherty L, Tocco P, Campos H (2005) Fasting whole blood as a biomarker of essential fatty acid intake in epidemiologic studies: comparison with adipose tissue and plasma. Am J Epidemiol 162:373-381

Bearhop S, Thompson DR, Phillips RA, Waldron S and 5 others (2001) Annual variation in great skua diets: the importance of commercial fisheries and predation on seabirds revealed by combining dietary analyses. Condor 103: 802-809

Bertellotti M, Yorio P (2000) Utilisation of fishery waste by Kelp Gulls attending coastal trawl and longline vessels in northern Patagonia, Argentina. Ornis Fenn 77:105-115

Budge SM, Iverson SJ, Bowen WD, Ackman RG (2002) Among- and within-species variability in fatty acid signatures of marine fish and invertebrates on the Scotian Shelf, Georges Bank, and southern Gulf of St. Lawrence. Can J Fish Aquat Sci 59:886-898

Caldow RWG, Furness RW (2000) The effect of food availability on the foraging behaviour of breeding great skuas Catharacta skua and Arctic skuas Stercorarius parasiticus. J Avian Biol 31:367-375

Chapdelaine G, Rail JF (1997) Relationship between cod fishery activities and the population of herring gulls on the north shore of the Gulf of St Lawrence, Quebec, Canada. ICES J Mar Sci 54:708-713

Dahl TM, Falk-Petersen S, Gabrielsen GW, Sargent JR, Hop H, Millar RM (2003) Lipids and stable isotopes in common eider, black-legged kittiwake and northern fulmar: a trophic study from an Arctic fjord. Mar Ecol Prog Ser 256: 257-269

Dalsgaard J, St John M, Kattner G, Müller-Navarra D, Hagen W (2003) Fatty acid trophic markers in the pelagic marine environment. Adv Mar Biol 46:225-340

Davis SE, Nager RG, Furness RW (2005) Food availability affects adult survival as well as breeding success of parasitic jaegers. Ecology 86:1047-1056

Ellis HI, Gabrielsen GW (2002) Energetics of free-ranging seabirds. In: Schreiber EA, Burger J (eds) Biology of marine birds. CRC Press, Boca Raton, FL, p 359-407

Foglia TA, Cartwright AL, Gyurik RJ, Philips JG (1994) Fatty acid turnover rates in the adipose tissues of the growing chicken (Gallus domesticus). Lipids 29:497-502

Folch J, Lees M, Sloane-Stanley GH (1957) A simple method for the isolation and purification of total lipides from animal tissues. J Biol Chem 226:497-509

Furness RW (1987) The skuas. T \& AD Poyser, Calton

Furness RW (2002) Management implications of interactions between fisheries and sandeel-dependent seabirds and seals in the North Sea. ICES J Mar Sci 59:261-269

Furness RW (2003) Impacts of fisheries on seabird communities. Sci Mar 67:33-45

Furness RW, Hislop JRG (1981) Diets and feeding ecology of great skuas Catharacta skua during the breeding season in Shetland. J Zool Lond 195:1-23

Garthe S, Camphuysen CJ, Furness RW (1996) Amounts of discards by commercial fisheries and their significance as food for seabirds in the North Sea. Mar Ecol Prog Ser 136: $1-11$

Guglielmo CG, Williams TD, Zwingelstein G, Brichon G, Weber JM (2002) Plasma and muscle phospholipids are involved in the metabolic response to long-distance migration in a shorebird. J Comp Physiol B 172:409-417
Härkönen T (1986) Guide to the otoliths of the bony fishes of the Northeast Atlantic. Danbiu ApS, Hellerup

Heath RB, Karpe F, Milne RW, Burdge GC, Wootton SA, Frayn KN (2003) Selective partitioning of dietary fatty acids into the VLDL TG pool in the early postprandial period. J Lipid Res 44:2065-2072

Hertzberg GR, Skinner C (1997) Differential accumulation and release of long-chain n-3 fatty acids from liver, muscle, and adipose tissue triacylglycerols. Can J Physiol Pharmacol 75:945-951

Hobson KA, Clark RG (1992) Assessing avian diets using stable isotopes I: turnover of ${ }^{13} \mathrm{C}$ in tissues. Condor 94 : 181-188

Hüppop O, Wurm S (2000) Effects of winter fishery activities on resting numbers, food and body condition of large gulls Larus argentatus and L. marinus in the south-eastern North Sea. Mar Ecol Prog Ser 194:241-247

Iverson SJ, Frost KJ, Lang SLC (2002) Fat content and fatty acid composition of forage fish and invertebrates in Prince William Sound, Alaska: factors contributing to among and within species variability. Mar Ecol Prog Ser 241:161-181

Iverson SJ, Field C, Bowen WD, Blanchard W (2004) Quantitative fatty acid signature analysis: a new method of estimating predator diets. Ecol Monogr 74:211-235

Käkelä R, Käkelä A, Kahle S, Becker PH, Kelly A, Furness RW (2005) Fatty acid signatures in plasma of captive herring gulls as indicators of demersal or pelagic fish diet. Mar Ecol Prog Ser 293:191-200

Kalmbach E, Griffiths R, Crane JE, Furness RW (2004) Effects of experimentally increased egg production on female body condition and laying dates in the great skua Stercorarius skua. J Avian Biol 35:501-514

Katan MB, Deslypere JP, van Birgelen APJM, Penders M, Zegwaard M (1997) Kinetics of the incorporation of dietary fatty acids into serum cholesteryl esters, erythrocyte membranes, and adipose tissue: an 18-month controlled study. J Lipid Res 38:2012-2022

Kvalheim OM, Karstang T (1987) A general-purpose program for multivariate data analysis. Chemom Intel Lab Syst 2: 235-237

Mavor RA, Parsons M, Heubeck M, Schmitt S (2004) Seabird numbers and breeding success in Britain and Ireland, 2003. UK Nature Conservation no. 28. JNCC, Peterborough

Mitchell PI, Newton SF, Ratcliffe N, Dunn TE (2004) Seabird populations of Britain and Ireland. T \& AD Poyser, London

Newman RE, Bryden WL, Fleck E, Ashes JR, Buttemer WA, Storlien LH, Downing JA (2002) Dietary n-3 and n-6 fatty acids alter avian metabolism: metabolism and abdominal fat deposition. Br J Nutr 88:11-18

Oro D, Furness RW (2002) Influences of food availability and predation on survival of kittiwakes. Ecology 83:2516-2528

Oro D, Ruiz X (1997) Exploitation of trawler discards by breeding seabirds in the north-western Mediterranean: differences between the Ebro Delta and the Balearic Islands areas. ICES J Mar Sci 54:695-707

Oro D, Genovart X, Ruiz X, Jimenez J, Garcia-Gans J (1996) Differences in diet, population size and reproductive performance between 2 colonies of Audouin's gulls Larus audouinii affected by a trawling moratorium. J Avian Biol 27:245-251

Phillips RA, Furness RW (1997) Sex-specific variation in the loss of mass by breeding Arctic Skuas. J Avian Biol 28:163-170

Phillips RA, Catry P, Thompson DR, Hamer KC, Furness RW (1997) Inter-colony variation in diet and reproductive performance of great skuas Catharacta skua. Mar Ecol Prog Ser 152:285-293 
Raclot T (2003) Selective mobilization of fatty acids from adipose tissue triacylglycerols. Prog Lipid Res 42:257-288

Raclot T, Groscolas R, Cherel Y (1998) Fatty acid evidence for the importance of myctophid fishes in the diet of king penguins, Aptenodytes patagonicus. Mar Biol 132: 523-533

Saito H, Kotani Y (2000) Lipids of four boreal calanoid copepods: origin of monoene fats of marine animals at higher trophic levels in the grazing food chain in the subarctic ocean ecosystem. Mar Chem 71:69-82

Soriguer FJ, Tinahones FJ, Monzón A, Pareja A, RojoMartínez G, Moreno F, Esteva I, Gómez-Zumaquero JM (2000) Varying incorporation of fatty acids into phospholipids from muscle, adipose and pancreatic exocrine tissues and thymocytes in adult rats fed with diets rich in different fatty acids. Eur J Epidemiol 16:585-594

Stratoudakis Y, Fryer RJ, Cook RM, Pierce GJ (1999) Fish discarded from Scottish demersal vessels: estimators of total discards and annual estimates for targeted gadoids. ICES J Mar Sci 56:592-605

Editorial responsibility: Otto Kinne (Editor-in-Chief), Oldendorf/Luhe, Germany
Votier SC, Bearhop S, Ratcliffe N, Furness RW (2001) Pellets as indicators of diet in great skuas Catharacta skua. Bird Study 48:373-376

Votier SC, Bearhop S, MacCormick A, Ratcliffe NR, Furness RW (2003) Assessing the diet of great skuas, Catharacta skua, using 5 different techniques. Polar Biol 26:20-26

Votier SC, Furness RW, Bearhop S, Crane JE and 11 others (2004a) Changes in fisheries discard rates and seabird communities. Nature 427:727-730

Votier SC, Bearhop S, Ratcliffe N, Furness RW (2004b) Reproductive consequences for great skuas specializing as seabird predators. Condor 106:275-287

Watt J, Pierce GJ, Boyle PR (1997) Guide to the identification of North Sea fish using premaxillae and vertebrae. ICES Coop Res Rept No 220, ICES, Copenhagen

Wernham CV, Toms MP, Marchant JH, Clark JA, Siriwardena GM, Baillie SR (2002) The migration atlas: movements of the birds of Britain and Ireland. T \& AD Poyser, London

Zhou L, Nilsson $\AA$ (2001) Sources of eicosanoid precursor fatty acid pools in tissues. J Lipid Res 42:1521-1542

Submitted: April 27, 2005; Accepted: January 16, 2006

Proofs received from author(s): August 1, 2006 